Roger Williams University

DOCS@RWU

2012

\title{
Introduction: Why People Do Not Accept Evolution: Using Protistan Diversity to Promote Evolution Literacy
}

\author{
Guillermo Paz-y-Miño-C \\ University of Massachusetts Dartmouth \\ Avelina Espinosa \\ Roger Williams University, aespinosa@rwu.edu
}

Follow this and additional works at: https://docs.rwu.edu/fcas_fp

Part of the Biology Commons

\section{Recommended Citation}

Paz-y-Miño-C, Guillermo and Avelina Espinosa. 2012. "Introduction: Why People Do Not Accept Evolution: Using Protistan Diversity to Promote Evolution Literacy." Journal of Eukaryotic Microbiology 59 (2): 101-104.

This Article is brought to you for free and open access by the Arts and Sciences at DOCS@RWU. It has been accepted for inclusion in Arts \& Sciences Faculty Publications by an authorized administrator of DOCS@RWU. For more information, please contact mwu@rwu.edu. 


\title{
Introduction: Why People Do Not Accept Evolution: Using Protistan Diversity to Promote Evolution Literacy
}

\author{
GUILLERMO PAZ-Y-MIÑO-C. ${ }^{a}$ and AVELINA ESPINOSA ${ }^{\mathrm{b}}$ \\ ${ }^{a}$ Department of Biology, University of Massachusetts Dartmouth, North Dartmouth, Massachusetts 02747, USA, and \\ ${ }^{\mathrm{b}}$ Department of Biology, Roger Williams University, Bristol, Rhode Island 02809, USA
}

\begin{abstract}
The controversy evolution vs. creationism is inherent to the incompatibility between scientific rationalism/empiricism and the belief in supernatural causation. To test this hypothesis, we conceptualized a Cartesian landscape where the dependent variable acceptance of evolution was plotted as function of three factors, each represented by an index (value range 0 to 3): Religiosity Index $(R I)$, Science Index $(S I)$, and Evolution Index $(E I)$. The indexes summarized an individual's personal religious convictions, familiarity with the processes and forces of change in organisms (= concept of evolution), and understanding the essence of science (= method to explore reality). We compared and contrasted acceptance of evolution among four populations of variable educational attainment: 244 professors of New England, United States (93\% Ph.D./doctorate holders), 50 protistologists from 25 countries ( $70 \%$ Ph.D./doctorate holders), 62 educators of prospective teachers ( $83 \%$ Ph.D./doctorate holders), and 827 college students. The New England faculty held the highest acceptance of evolution position $(R I=0.49 ; S I=2.49 ; E I=2.49)$, followed by the protistologists $(R I=0.46 ; S I=2.30 ; E I=2.48)$, the educators of prospective teachers $(R I=0.83 ; S I=1.96 ; E I=$ $1.96)$, and the students $(R I=0.89 ; S I=1.80 ; E I=1.60)$; therefore, the data supported our hypothesis. Proper science education, public outreach and robust debate over the controversy "evolution versus creationism" should suffice to improve society's evolution literacy, and qualified scholars ought to lead this mission.
\end{abstract}

Key Words. Adaptation, history, protistology, protists.

$\mathrm{S}$ PONSORED by the International Society of Protistologists (ISOP) and the VI European Congress of Protistology held in July 25-29, 2011, at the Free University of Berlin, Germany, we organized a workshop entitled "Using the Diversity of Protists to Educate Students and the Public about Evolution." The workshop had three goals: (1) examine patterns of public acceptance of evolution worldwide to identify measurable variables associated with attitudes toward evolution; (2) strategize effective communication of evolutionary principles to all audiences and facilitate public outreach based on an empirical understanding of the conflicts between evolution and creationism; and (3) highlight the significance of protists as exemplars of evolutionary processes and use them to promote evolution literacy. This was the second workshop about the "controversy evolution vs. creationism" sponsored by ISOP; the first, entitled "Horizontal Gene Transfer and Phylogenetic Evolution Debunk Intelligent Design" was held at Roger Williams University, USA, in 2009 (Espinosa 2010; Farmer and Habura 2010; Paz-y-Miño-C. and Espinosa 2010).

Dr. Guillermo Paz-y-Miño-C., University of Massachusetts Dartmouth, USA, introduced the workshop by highlighting world patterns of acceptance of evolution and discussing why people do not accept evolution (details below); Drs Mark van der Giezen (speaker) and Timothy M. Lenton, University of Exeter, Great Britain, discussed the proto-world and the emergence of protists; Dr. Janet Keithly, Wadsworth Center, New York State Department of Health, USA, summarized the evolution of mitochondrion-like organelles; Dr. Avelina Espinosa, Roger Williams University, USA, discussed crypticity and incipient taxa in Entamoeba; and Drs Samuel Bowser (speaker), Jefrey Travis, and Andrea Habura, Wadsworth Center, New York State Department of Health, USA, portrayed foraminiferans as pontiffs of evolution.

Corresponding Author: G. Paz-y-Miño-C., Department of Biology, University of Massachusetts Dartmouth, 285 Old Westport Road, North Dartmouth, Massachusetts 02747-Telephone number: 508999 8226; FAX number: 508999 8196; e-mail: gpazymino @ umassd.edu

${ }^{1}$ Presentation delivered at the symposium: Using the Diversity of Protists to Educate Students and the Public about Evolution, VI European Congress of Protistology, Free University of Berlin, July 25-29, 2011, Berlin, Germany.
The researchers above agreed to summarize the workshop by preparing three articles which are published in this issue of the Journal of Eukaryotic Microbiology: first, this Introduction to the workshop on Why People Do Not Accept Evolution: Using Protistan Diversity to Promote Evolution Literacy, by Paz-y-Miño-C. and Espinosa; second, a critical mini-review of contrasting hypothesis concerning the Rise of Oxygen and Complex Life, by van der Giezen and Lenton; and third, a laboratory-based study on Discrimination, Crypticity and Incipient Taxa in Entamoeba, by Espinosa and Paz-y-Miño-C.

In this Introduction, we summarize Paz-y-Miño-C.'s analysis of the statistical patterns of acceptance of evolution worldwide and his conceptual discussion about why people do not accept evolution, particularly the interaction between science/ evolution literacy and the belief in supernatural causation. We close by highlighting descriptive statistics about attitudes toward evolution among protistologists in comparison to other highly educated scholars.

\section{A GLANCE AT WORLD STATISTICS ON ACCEPTANCE OF EVOLUTION}

Based on current scientific evidence, $100 \%$ of all people should accept the concept of evolution, which proposes naturalistic explanations about the origin of the universe $(=$ cosmic evolution; Krauss 2010), its gradual processes of change including the origin of life, its diversification, and the synergistic phenomena resulting from the interaction between life and the environment (Paz-y-Miño-C. and Espinosa 2011a). However, only $41 \%$ of adults worldwide (24 countries, $N=18,829$ ) accept evolution, and they do it under the premise that a deity created humans; $31 \%$ do not know whom to trust in matters of evolution, neither scientists or spiritualists; and $28 \%$ are strict creationists who believe in religious scriptures concerning the origin of our universe and of humans (e.g. Genesis: the creation of the universe by God a few thousand years ago $=$ Young Earth Creationists), and explicitly reject the fact that humans are apes (IPSOS 2011).

Among the $41 \%$ (above) of citizens who accept evolution conditionally (i.e. think that the evolutionary process is true, but humans were specially created), the range of opinions by nation is evident $(r=7-68 \%)$. Among the top countries are 
Sweden (68\%), Germany (65\%), China (64\%), Japan (60\%), and Great Britain and France (55\%). In the middle are Spain $(53 \%)$, Australia $(51 \%)$, Canada $(45 \%)$, South Korea $(41 \%)$, Italy $(40 \%)$, and Argentina $(37 \%)$. And in the bottom are Mexico (34\%), the United States (28\%), Russia (26\%), Brazil $(22 \%)$, Turkey $(19 \%)$, Indonesia $(11 \%)$, and Saudi Arabia (7\%) (not all countries listed here; IPSOS 2011).

Among the $28 \%$ of creationists (above), who believe in religious scripture and emphasize - wrongly - that humans cannot possibly be apes, the range of views by nation is conspicuous $(r=8-75 \%)$. Among the top countries are Saudi Arabia $(75 \%)$, Turkey $(60 \%)$, Indonesia $(57 \%)$, Brazil $(47 \%)$, the United States $(40 \%)$, Russia $(34 \%)$, and India $(33 \%)$. In the middle are Mexico (32\%), South Korea (24\%), Canada $(22 \%)$, Italy $(21 \%)$, and Australia $(15 \%)$. In the bottom are Germany $(12 \%)$, Great Britain (12\%), China and Japan (11\%), France $(9 \%)$, and Belgium (8\%) (not all countries listed here; IPSOS 2011).

Public acceptance of evolution is particularly high among prosperous nations (e.g. Sweden, Germany, Belgium, Japan, France, Great Britain, data above; see also Miller, Scott, and Okamoto 2006), except for the United States where only one in three adults thinks evolution is true (IPSOS 2011; Miller et al. 2006). In fact, the United States is the only outlier, among other wealthy nations (i.e. per capita Gross Domestic Product GDP $\approx \$ 50,000$ ), whose level of religiosity is much higher (1.4 vs. 0.6 in a scale from 0 to 3 , or least to most religious) than its Eastern and Western European counterparts (The Pew Global Attitudes Project 2007); note that level of religiosity is negatively associated with acceptance of evolution (below).

Geographically, world Christians in six continents (North America 30\%; South America 30\%; Europe and Great Britain $50 \%$; Asia $30 \%$; Africa $25 \%$; and Australia $30 \%$; data extracted from Wilson 2010) accept evolution more than Muslims in Turkey (19-22\%), Indonesia (11-16\%), Pakistan (14\%), Malaysia (12\%), and Egypt (8\%), except for Kazakhstan (38\%) (data extracted from IPSOS 2011; Hameed 2008).

\section{WHY PEOPLE DO NOT ACCEPT EVOLUTION}

To test the hypothesis that the controversy evolution vs. creationism is inherent to the incompatibility between scientific rationalism/empiricism and the belief in supernatural causation, we (Paz-y-Miño-C. and Espinosa, this article) have conceptualized a simple approach (Fig. 1), which relies on the analysis of three factors associated with an individual's acceptance of evolution (Bishop and Anderson 1990; Downie and Barron 2000; Paz-y-Miño-C. and Espinosa 2009a,b, 2011a,b; Trani 2004): understanding the essence of science (= method to explore reality), familiarity with the processes and forces of change in organisms (= concept of evolution), and personal religious convictions. The dependent variable acceptance of evolution can be plotted in a three-dimensional Cartesian coordinate landscape where the independent variables, personal religious convictions, understanding how evolution works, and understanding the essence of science, occupy the axes $x, y$, and $z$, respectively (Fig. 1). The point zero, from which the coordinates originate, corresponds to a low (labeled none) religiosity, evolution, or science awareness condition, or a no awareness corner, which is a low probability of occurrence (LPC) corner. Away from zero, the tips of the coordinates' arrows correspond to a high or deep religiosity, evolution, or science awareness. The highest acceptance of evolution corner is located in the top right of the landscape, where religiosity is low or none and evolution and science awareness are high or

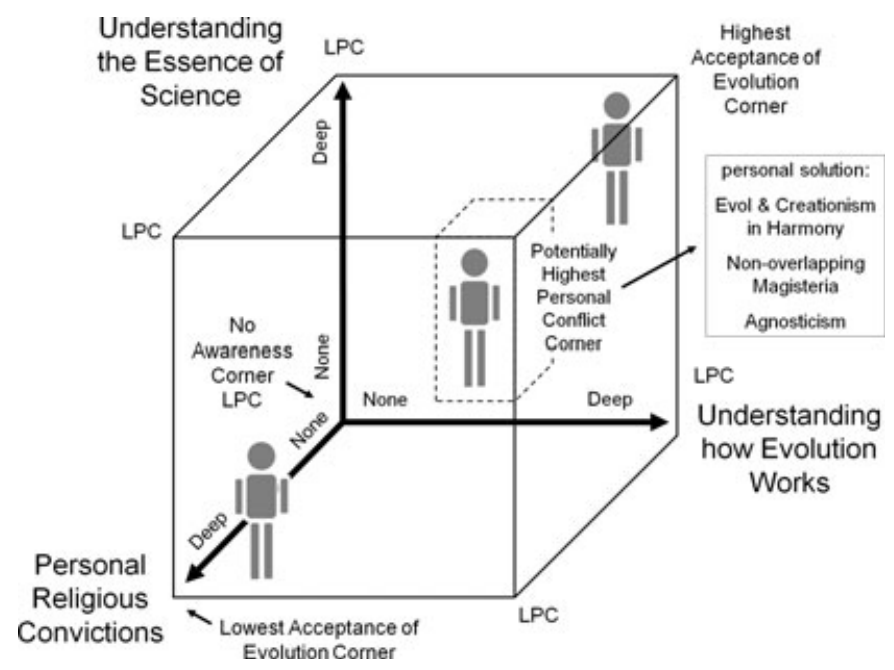

Fig. 1. Conceptual and quantitative assessment of acceptance of evolution. Theoretical three-dimensional landscape where acceptance of evolution is depicted as function of religiosity, science awareness, and evolution literacy. The point zero corresponds to low/none personal religious convictions, understanding how evolution works, or understanding of the essence of science; zero is a no awareness corner, with low probability of occurrence (LPC). The tips of the coordinates' arrows correspond to a high/deep religiosity, evolution, or science awareness. The highest acceptance of evolution corner (top right) is characterized for its low religiosity and high/deep evolution and science awareness. The lowest acceptance of evolution corner (bottom left) is characterized by its high religiosity and low evolution and science awareness. A potentially highest personal conflict corner resides at the intersection of high or deep religiosity and evolution and science awareness; this conflict condition can be resolved by the individual adopting comforting positions, such as evolution and creationism are in harmony, nonoverlapping magisteria (= science and religion occupy separate domains), or agnosticism (doubt about the existence or nonexistence of a deity). Other corners are also labeled LPC due to their low probability of occurrence.

deep. The lowest acceptance of evolution corner is located in the bottom left of the landscape, where religiosity is high or deep and evolution and science awareness are low or none. A potentially highest personal conflict corner resides at the intersection of high or deep religiosity and evolution and science awareness; this potential conflict condition, however, can be resolved by the individual adopting comforting positions, such as evolution and creationism are in harmony, nonoverlapping magisteria $(\mathrm{NOMA}=$ science and religion occupy separate domains; Gould 1999), or agnosticism (doubt about the existence or nonexistence of a deity). Note that four other corners are labeled LPC in Fig. 1 due to their LPC (e.g. high or deep understanding of science combined with no understanding of evolution and no religiosity, which is unlikely).

To quantitate the levels of religiosity, understanding of science and the evolutionary process and plot them according to the parameters depicted in Fig. 1, we followed Paz-y-Miño-C. and Espinosa (2011b) and (in press) who have used three descriptive indexes as characterizers of acceptance of evolution, each ranging from 0 to 3 (least to most religious or knowledgeable about science or evolution): Religiosity Index (RI) (The Pew Global Attitudes Project 2007), Science Index $(S I)$, and Evolution Index (EI) (Paz-y-Miño-C. and Espinosa $2011 \mathrm{~b}$, in press). These indexes are powerful predictors of religious views worldwide (47 countries; The Pew Global Attitudes Project 2007) and of levels of understanding science and the evolutionary process (e.g., sample of 1,133 USA adults 


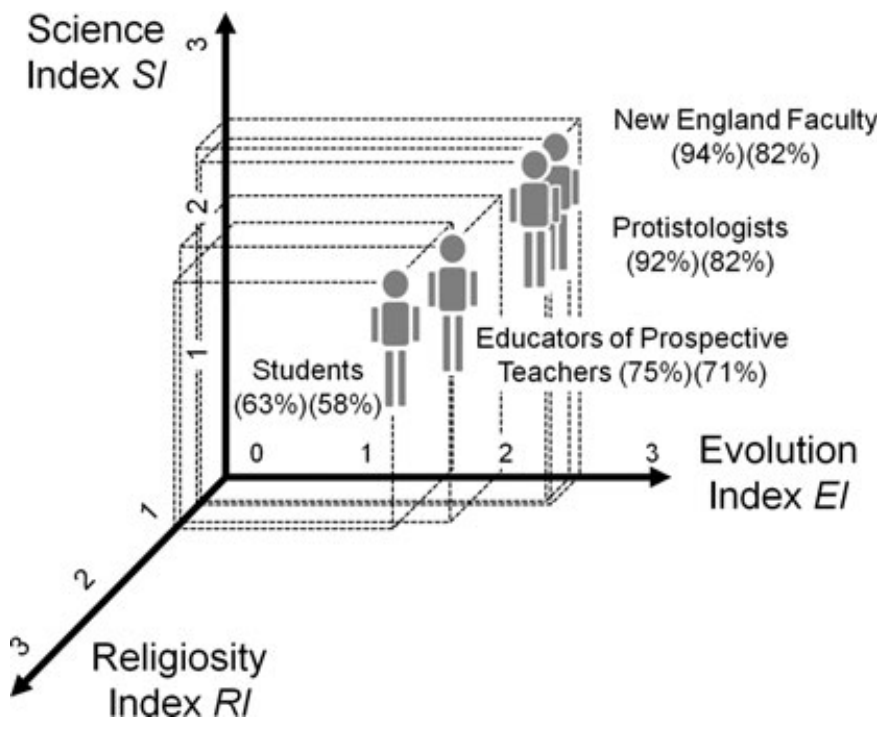

Fig. 2. Acceptance of evolution plotted as function of religiosity $(R I)$, science $(S I)$, and evolution $(E I)$ indexes. Each index ranges from 0 to 3 (least to most religious or knowledgeable about science or evolution; see text for details). The three-dimensional landscape is consistent with the theoretical parameters depicted in Fig. 1. The New England faculty held the highest acceptance of evolution position $(N=244 ; R I=0.49 ; S I=2.49 ; E I=2.49)$, followed by protistologists $(N=50 ; R I=0.46 ; \quad S I=2.30 ; E I=2.48)$, educators of prospective teachers $(N=62 ; R I=0.83 ; \quad S I=1.96 ; \quad E I=1.96)$, and students $(N=827 ; R I=0.89 ; S I=1.80 ; E I=1.60)$. Percentage values written within brackets correspond to responders admitting to accept evolution openly regardless of others opinions (first value) or thinking that evolution is definitely true (second value).

with diverse academic backgrounds, from college students to university professors; Paz-y-Miño-C. and Espinosa 2011b, in press). Each index relies on examining responses to simple, informative questions: $R I:+1$ if responders believe that faith in God is necessary for morality, +1 if religion is very important in their lives, and +1 if they pray daily. SI: +1 if responders reject the idea that scientific theories are based on opinions by scientists, +1 if they disagree with the notion that scientific arguments are as valid and respectable as their nonscientific counterparts, and +1 if they reject the statement that crime-scene and accident-scene investigators use a different type of scientific method to investigate a crime or an accident; $E I:+1$ if responders reject the idea that organisms acquire beneficial traits during their lifetimes and then pass on these traits to their descendants, +1 if they disagree with the notion that during evolution monkeys such as chimpanzees can turn into humans, and +1 if they reject the statement that the origin of the human mind and consciousness cannot be explained by evolution.

Paz-y-Miño-C. and Espinosa (in press) have applied this methodology to assess attitudes toward science and patterns of acceptance of evolution as function of religiosity at $35 \mathrm{col}-$ leges and universities in New England, one of the most progressive and highly educated regions in Northeastern United Sates. They sampled 244 general faculty $(93 \% \mathrm{Ph} . \mathrm{D}$./doctorate holders in 40 disciplines), 62 educators of prospective teachers ( $87 \%$ Ph.D./doctorate holders in 32 specializations), and 827 college students. The general faculty were the most knowledgeable about science/evolution and the least religious $(S I=2.49 ; E I=2.49$; and $R I=0.49)$; the educators reached lower science-/evolution-but higher religiosity_indexes than the general faculty $(S I=1.96 ; E I=1.96$; and $R I=0.83)$; and the students were the least knowledgeable about science/evolution and the most religious $(S I=1.80 ; E I=1.60 ;$ and $R I=0.89)$. These indexes were associated with overall acceptance of evolution: $94 \%$ of the general faculty, $75 \%$ of the educators, and $63 \%$ of the students admitted to accept evolution openly; and $82 \%$ of the general faculty, $71 \%$ of the educators, and $58 \%$ of the students thought that evolution is definitely true (Fig. 2).

To compare the indexes and statistics of the New England faculty (above) with those of an international, highly specialized, and educated group of scholars, we surveyed in situ the protistologists who attended the VI European Congress of Protistologists at the Free University of Berlin, which included 272 participants $(70 \% \mathrm{Ph}$.D./doctorate holders) from 30 countries. Fifty protistologists $(18 \%)$ from 25 countries $(83 \%)$ completed an online survey distributed via email (survey accessible July 26-29, 2011); their SI and EI were slightly lower than the New England faculty (SI: 2.30 vs. 2.49; EI: 2.48 vs. 2.49 ), but the protistologists were slightly less religious than the USA professors (RI: 0.46 vs. 0.49 ). Interestingly, $92 \%$ of the protistologists vs. $94 \%$ of the New England faculty admitted to accept evolution openly, and $82 \%$ of both groups agreed that evolution is definitely true (Fig. 2).

Other interesting findings about protistologists (P) vs. New England faculty (F) included (1) $83 \% \mathrm{P}$ vs. $91 \% \mathrm{~F}$ indicated to be very or somewhat concerned about the controversy over evolution vs. creationism vs. intelligent design and its implications for science education; (2) $45 \% \mathrm{P}$ vs. $47 \% \mathrm{~F}$ thought that intelligent design is not scientific, but has been proposed to counter evolution based on false claims, and $40 \% \mathrm{P}$ vs. $46 \%$ $\mathrm{F}$ considered intelligent design to be a doctrine consistent with creationism; (3) $94 \% \mathrm{P}$ vs. $96 \% \mathrm{~F}$ considered that evolution alone should be taught in science classes, and $6 \% \mathrm{P}$ vs. $4 \% \mathrm{~F}$ favored "equal time" to evolution, creationism, and intelligent design; (4) $92 \% \mathrm{P}$ vs. $94 \% \mathrm{~F}$ indicated to accept evolution openly regardless of others opinions and $4 \% \mathrm{P}$ vs. $2 \% \mathrm{~F}$ admitted to be creationists; (5) $90 \% \mathrm{P}$ vs. $98 \% \mathrm{~F}$ preferred if college/school instructors teach science courses where evolution is discussed comprehensively and humans are part of it; (6) $76 \%$ $\mathrm{P}$ vs. $80 \% \mathrm{~F}$ agreed with the statement that evolution is a gradual process by which the universe changes, it includes the origin of life, its diversification, and the synergistic phenomena resulting from the interactions between life and the environment; (7) $94 \% \mathrm{P}$ vs. $92 \% \mathrm{~F}$ disagreed with the statement that it is possible to offer an excellent biology course for college students that includes no mention of Charles Darwin or the theory of evolution; (8) $88 \%$ P vs. $91 \%$ F disagreed with the notion that many reputable scientists view creationism and intelligent design as valid alternatives to the theory of evolution; (9) $12 \% \mathrm{P}$ vs. $15 \% \mathrm{~F}$ though erroneously that the origin of the human mind and consciousness cannot be explained by evolution, $12 \% \mathrm{P}$ vs. $26 \% \mathrm{~F}$ did not know that humans are apes, and $30 \%$ of both $\mathrm{P}$ and $\mathrm{F}$ were Lamarckian, i.e. believed in the inheritance of acquired traits during organisms' life times; and (10) $76 \% \mathrm{P}$ vs. $62 \% \mathrm{~F}$ agreed with the statement that a future catastrophic collision between Earth and a large asteroid or comet will happen.

\section{CONCLUSIONS}

World patterns of acceptance of evolution suggest that attitudes toward evolution are associated with three significant factors: religiosity, science, and evolution literacy (data analysis this article). Highly industrialized and prosperous nations rank higher $(>55 \%)$ than developing countries $(<40 \%)$ in 
public acceptance of evolution, except the United States $(28 \%)$ (data extracted and rounded up from IPSOS 2011; Miller et al. 2006), and world Christians accept evolution more $(>30 \%)$ than world Muslims $(<30 \%)$ (data extracted and rounded up from Hameed 2008; Wilson 2010). Open acceptance of evolution is highest among highly educated audiences, like the university professors of New England, USA, $(94 \%)$ and protistologists $(92 \%)$ from 25 countries (Paz-y-Miño-C. and Espinosa 2011b; this article). Proper science education, public outreach, and robust debate over the controversy "evolution vs. creationism" should suffice to improve society's evolution literacy; therefore, protistologists, as qualified scholars, can lead this mission.

\section{ACKNOWLEDGMENTS}

We thank the International Society of Protistologists and the organizers of the VI European Congress of Protistology for sponsoring the workshop "Using the Diversity of Protists to Educate Students and the Public about Evolution," and the Free University of Berlin for hosting it. Klaus Hausmann and Renate Radek distributed the online survey and provided data on congress attendees by country. The Institutional Review Board at the University of Massachusetts Dartmouth (UMassD-IRB) approved the survey. G. Paz-y-Miño-C. is supported by the UMassD Office of Faculty Development (Award AY0910; Grant F09) and A. Espinosa by NIHNCRR grant \#2 P20RR16457-11.

\section{LITERATURE CITED}

Bishop, B. A. \& Anderson, C. W. 1990. Student conceptions of natural selection and its role in evolution. J. Res. Sci. Teaching, 27:415427.

Downie, J. R. \& Barron, N. J. 2000. Evolution and religion: attitudes of Scottish first year biology and medical students to the teaching of evolutionary biology. J. Biol. Education, 34:140-146.

Espinosa, A. 2010. Introduction: protistan biology, horizontal gene transfer, and common descent uncover faulty logic in intelligent design. J. Eukaryot. Microbiol., 57:1-2.
Farmer, M. A. \& Habura, A. 2010. Using protistan examples to dispel the myths of intelligent design. J. Eukaryot. Microbiol., 57:310.

Gould, S. J. 1999. Rocks of Ages. Ballantine Books, New York, $241 \mathrm{p}$.

Hameed, S. 2008. Bracing for Islamic creationism. Science, 322:16371638.

IPSOS. 2011. Supreme being, the afterlife, and evolution. Available at: http://www.ipsos-na.com/news-polls/pressrelease. $\operatorname{aspx} ? \mathrm{id}=5217$ [accessed on 22 December 2011]

Krauss, L. M. 2010. Cosmic evolution. Evo. Edu. Outreach, 3:193197.

Miller, J. D., Scott, E. C. \& Okamoto, S. 2006. Public acceptance of evolution. Science, 313:765-766.

Paz-y-Miño-C., G. \& Espinosa, A. 2009a. Assessment of biology majors versus non-majors views on evolution, creationism and intelligent design. Evo. Edu. Outreach, 2:75-83.

Paz-y-Miño-C., G. \& Espinosa, A. 2009b. Acceptance of evolution increases with student academic level: a comparison between a secular and a religious college. Evo. Edu. Outreach, 2:655-675.

Paz-y-Miño-C., G. \& Espinosa, A. 2010. Integrating horizontal gene transfer and common descent to depict evolution and contrast it with 'common design'. J. Eukaryot. Microbiol., 57:11-18.

Paz-y-Miño-C., G. \& Espinosa, A. 2011a. On the theory of evolution versus the concept of evolution: three observations. Evo. Edu. Outreach, 2:308-312.

Paz-y-Miño-C., G. \& Espinosa, A. 2011b. New England faculty and college students differ in their views about evolution, creationism, intelligent design, and religiosity. Evo. Edu. Outreach, 2:323-342.

Paz-y-Miño-C., G. \& Espinosa, A. In press. Educators of prospective teachers hesitate to embrace evolution due to deficient understanding of science/evolution and high religiosity. Evo. Edu. Outreach.

The Pew Global Attitudes Project. 2007. World Publics Welcome Global Trade but Not Immigration. Pew Research Center, Washington, DC. Available at: http://pewglobal.org/files/pdf/258.pdf [accessed on 17 January 2012].

Trani, R. 2004. I won't teach evolution; it's against my religion. And now for the rest of the story.... Amer. Biol. Teacher, 66:419-427.

Wilson, D. P. 2010. European Christians are at the forefront in accepting evolution: results from an internet-based survey. Evol. Develop., 12:537-540.

Received: 11/20/11, 12/01/11; accepted: 12/05/11 